\title{
THE PROGRESS OF THE SPANISH-AMERICAN COUNTRIES
}

\author{
By His Excellency, Senor Don Ignacio Calderon, \\ Envoy Extraordinary and Minister Plenipotentiary of Bolivia to the United \\ States.
}

I feel highly honored to be called upon to address such an im. portant and learned assembly and to have an opportunity of making a few remarks about my own country.

When the Pilgrims abandoned the home of their fathers for conscience sake and undertook to cross the ocean to seek their freedom, everything before them was uncertain, except their faith in God and their deep and strong love of justice and right. They brought with them and propagated in the New World all the virtues that go to make a man a true and worthy image of his Maker, and from such seed has developed a nation that in due course of time has come to be, not only a great world power, but the sacred asylum for all liberty-loving people.

Great as is your material wealth, astonishing as is your progress and the development of your industries and commerce, and amazing as is the accumulation of wealth and the well being of the majority of the people of the United States, nothing appeals with greater force to my mind than the practical working of the principle of equality and freedom, limited only by law, which fact I consider as the mainspring of all your advancement.

When I contemplate the humblest citizen enjoying all the privileges and having open to him all the honors and all the rights that in some other nations are the patrimony of the few, I cannot help exclaim that American democracy is truly the consummation of the conquests of liberty and justice in the world.

Now, on the other hand, if you please, remember for a moment how different was the material that came to colonize and settle the other portion of the American continent; when you consider that the men who conquered Peru and Mexico were nothing but adventurers, seeking for gold and the satisfaction of their hunger for 
wealth; that after vanquishing and destroying highly organized nations, subjugated their inhabitants to serfdom; that the history of the three centuries of Spanish dominion is only a long chain of despotism and tyranny, you readily understand that when the LatinAmerican Republics, after long years of fighting for their freedom, succeeded at last and made themselves independent through their own exertions, their traditions and their education were far from suited to the proper exercise of free and orderly government. Even the geographical formation of our countries presents obstacles that do not exist in this Republic. That is why during the early years of their independence, and for some of them even up to this day, they had to pass through a dark period of formation and revolutions. Fortunately the majority of the republics of South America have entered firmly upon an era of peaceful development of their natural resources under well established governments.

There is a wrong propensity in this country to lump as one the different Republics of the South, and thus form a misleading opinion about their condition and progress.

Bolivia had also an epoch of misfortunes, and after sad experiences that cost her the loss of much of her territory, is now earnestly seeking to develop her great wealth and future.

Her mineral resources are second to none, and the Bolivian mountains contain a wonderful variety of minerals. The silver mines of Potosi are famous in the history of the world, and have contributed largely to its wealth. Silver, copper, antimony, bismuth, gold, and, at present, tin rank highest among the many minerals her territury produces. An Italian scientist, Mr. Raymondi, who made a life study of Peru, has called Bolivia a silver table standing on legs of gold.

The Andes divide themselves in Bolivian territory into two big branches. One towards the coast forms the western Cordillera, and the other, leading towards the east, is called the Cordillera real. Between these two branches extends the high plateau where most of the mineral wealth is to be found. In the eastern section are the vast virgin forests, where rubber, Peruvian bark and a great many other medicinal plants, and all kinds of fine woods grow luxuriantly. The reason why in the commerce of the world a great many of these Bolivian products are not known as such, is because they pass through the territory of neighboring republics and are 
shipped from their ports. The Bolivian copper, for instance, passing through Chilian ports, is considered as Chilian copper. The Bolivian rubber shipped at Para is called Para rubber, etc.

My government is at present endeavoring to build a system of railways that will connect the north and the south of the country and facilitate the development of its resources. An idea of their importance may be gotten from the fact that in a few years, and notwithstanding the absolute lack of means of transportation and without the proper machinery, we have increased our exports of tin from about 2,000 tons of crude ore to 25,000 tons last year. It is also a remarkable fact that Bolivia is the only tin-producing country in both Americas, and as this metal is found almost all over the country, its future is great.

The United States, I understand, consumes for its industries about 43 per cent. of the tin in the world, and for want of banking facilities and direct transportation from South America here, you are compelled to get the Bolivian tin via Europe, and this is the case with many other South American products, which are freely imported to England, France, and Germany.

When the railways now being surveyed are completed one of the most important links of the Pan-American system will be made, and then it will be possible to go by rail over a distance of about 2.000 miles, from La Paz, in Bolivia, to Buenos Ayres, in the Argentine.

Peru is also developing its railway system, and in the near future Lima, La Paz and Buenos Ayres, and even Santiago, in Chile, will be united by rail over the length of the South American continent, through a net of railroads more than three thousand miles in length.

Bolivia is absolutely free from any foreign debts, and instead of owing any money has at its disposal ten million dollars in gold to be devoted to the building of railways; and her revenues are sufficient not only to pay all the expenses of the administration, but to leave some surplus to pay the interest of the money that we are seeking to find for the construction of the roads I have described.

We shall welcome the aid of the capital and the enterprising spirit of the United States, and I earnestly hope that the leading men of this country will pay more attention to the great possibilities open to American capital in every one of the South American countries, 
and that coming into closer contact the peoples of the North and of the South will learn to understand each other better, and to realize that South America is not a field for revolutions only, and that its people are just as progressive and ready for advancement as any in the world. By this means a true Pan-American feeling may be developed in a great democratic brotherhood based on the mutual respect and estimation of its citizens. 